\title{
Application of statistical modelling of mixtures in the development of gluten-free bread with maca, potato, sweet and sour manioc
}

\author{
Aplicación de planificación de mezclar en el desarrollo de un pan \\ sin gluten con maca, patata, yuca dulce y agria
}

\begin{abstract}
This study describes the development of mixed flour added of maca for gluten-free bread (GFB) employing a Simplex Centroid Design. Four pseudo-components were evaluated in order to improve the GFB specific volume and texture profile analysis: maca (MC; 0.25 to 0.75 ), potato starch (PS; 0.25 to 0.75 ), sweet manioc flour (SEM; 0 to 0.25), and sour manioc flour (SOM; 0 to 0.25$)$. The best GFB formulation - by desirability results - was evaluated regarding physio-chemical, microbiological aspects, and sensory acceptance. The responses specific volume and hardness were adjusted with a special cubic model $\left(R^{2}=0.973\right.$ and 0.913), while cohesiveness, springiness and chewiness was adjusted with a linear model. The significant contribution of maca into GFB dough was evident in the models, and the desirability results indicated an appropriate mixed flour composed by MC (0.25), PS (0.5), and SEM (0.25). The GFB elaborated with this mixed flour generated a product well accepted (acceptability index higher than $73.9 \%$ ) for attributes of aroma, colour, texture, flavour, and overall acceptance. The values of physiochemical parameters obtained in the present article was in the range described for GFB in the literature. In addition, the processing method applied allowed for obtaining a GFB that was microbiologically stable. Keywords: Celiac disease; Maca Peruvian; Sensory acceptance; Specific volume; Texture profile analysis.
\end{abstract}

\section{RESUMEN}

Este estudio describe el desarrollo de la harina mezclada (MF) agregada de maca para la elaboración de pan sin gluten (GFB) empleando un Diseño Centroide Simplex. Se evaluaron cuatro pseudo-componentes para mejorar el volumen específico y el perfil de textura de GFB: maca (MC; 0,25 a 0,75), almidón de patata (PS; 0,25 a 0,75), harina de yuca dulce (SEM; 0 a 0,25), y harina de yuca agrio (SOM; 0 a 0,25). La mejor formulación de GFB - por la deseabilidad - se evaluó en relación con los aspectos fisicoquímicos, microbiológicos, y sensoriales. El volumen específico
Flora Miranda Arcanjo ${ }^{1}$, Nádia Cristiane Steinmacher ${ }^{1}$, Daneysa Lahis Kalschne ${ }^{1 *}$, Anandra Bedendo ${ }^{1}$, Aloisio Henrique Pereira de Souza ${ }^{3}$, Nilson Evelázio de Souza ${ }^{4}$, Angela Claudia Rodrigues ${ }^{2}$.

\footnotetext{
1. Departamento de Alimentos, Universidade Tecnológica Federal do Paraná, Medianeira, Paraná, Brazil.

2. Departamento de Química, Universidade Tecnológica Federal do Paraná, Medianeira, Paraná, Brazil. 3. Departamento de Alimentos, Instituto Federal de Mato Grosso do Sul, Coxim, Mato Grosso do Sul, Brazil.

4. Departamento de Química, Universidade Estadual de Maringá, Maringá, Paraná, Brazil.

*Corresponding author: Daneysa Lahis Kalschne, Avenida Brasil, 4232, Parque Independência, Medianeira, Paraná, Brazil. Email: daneysakalschne@utfpr.edu.br
}

Este trabajo fue recibido el 27 de febrero de 2019. Aceptado con modificaciones: 11 de diciembre de 2019 . Aceptado para ser publicado: 27 de diciembre de 2019.

y la dureza se ajustaron a un modelo cúbico especial $\left(R^{2}=0,975\right.$ y 0,913). La cohesión, elasticidad y masticabilidad se ajustaron a un modelo lineal. La contribución de la maca a la masa de GFB fue evidente en los modelos, y los resultados indican una MF apropiada compuesta por MC $(0,25)$, PS $(0.5)$ y $\operatorname{SEM}(0,25)$. El GFB elaborado con esta MF genera un producto aceptado (índice de aceptabilidad mayor que 73,9\%) para aroma, color, textura, sabor y aceptación general. Los parámetros físico-químicos obtenidos estaban en el rango descrito para GFB en la literatura y GFB se mostró microbiológicamente estable.

Palabras clave: Aceptación sensorial; Enfermedad celíaca; Maca peruana; Perfil de textura; Volumen específico. 


\section{INTRODUCTION}

Celiac disease is an intolerance to gluten intake developed by genetically predisposed individuals, which causes inflammatory processes in the small intestine, atrophy of intestinal villi, a deficient absorption of nutrients (vitamins, iron and calcium), and symptoms such as abdominal distension, flatulence, iron deficiency anaemia and osteoporosis ${ }^{1,2}$. Gluten is divided into two fractions regarding solubility - glutenin and gliadin - that have the property of forming, together with water, a viscoelastic and water-insoluble substance, responsible for the texture of bread. Celiac disease is prevalent in $1 \%$ of the world's population and the treatment includes the exclusion of gluten from the $\operatorname{diet}^{2,3}$. In this context, there is a growing interest among consumers for gluten-free products. Among all functional, natural or healthy-profile food categories, gluten-free products have the highest growth forecast in Brazil through 2022, with an estimated increase in sales between $35 \%$ and $40 \%$ per year ${ }^{4}$.

Gluten-free bread (GFB) is recognized by its poor technological quality, showing low specific volume, high crumb hardness, crumbling texture, poor color, and a high staling rate, however, it is an alternative for consumption among individuals with celiac disease $\mathrm{e}^{5,6}$. Thus, different flours, starches, enzymes, proteins and hydrocolloids have been tested in order to improve the structural acceptability of the product ${ }^{7}$. All technological advances in GFB production are welcome, although it is important to emphasize that the nutritional aspect improvement is also extremely recommended for celiac individuals. This specific group of consumers need to compensate for the deficient absorption of nutrients by eating foods rich in vitamins, iron and calcium ${ }^{1,2}$. Thus, the enrichment of flours and starches used as a GFB base can improve the health of celiac individuals, since these ingredients are not commonly enriched or fortified as is the case with wheat flour $^{8}$. Additionally, carbohydrates consumed in the glutenfree diet are mostly refined. During refining, the outer layer of grain - which contains the highest amount of fiber and minerals - is removed, leaving only the starchy inner layer, which is typically nutrient-poor ${ }^{9}$.

Regarding flour enrichment for GFB elaboration, researchers have demonstrated significant results using amaranth, buckwheat, chestnut, chia, linseed, soybean, and quinoa flours as a strategy to increase the fatty acids, fiber, protein and mineral content $t^{6,10,11,12,13,14,15}$. However, we have not found in the literature research reporting on the addition of maca to GFB.

Maca root (Lepidium meyenii) is a tuber native to the Andean region and grows exclusively above $4000 \mathrm{~m}$ altitude in the Peruvian Central Andes, which is why it is called Peruvian maca. Some researchers have reported on the medicinal properties of maca that can contribute to the treatment of osteoporosis, prostate disease including hyperplasia, fertility, spermatogenesis, in addition to depression, fatigue, anaemia, neuroprotective effects and in memory, and antioxidant activity ${ }^{16,17,18,19}$. Maca stands out for presenting antioxidant functions, presenting polysaccharides with potent free hydroxyl and superoxide radical scavenging activities $^{20}$ and has an iron, phosphorous and calcium

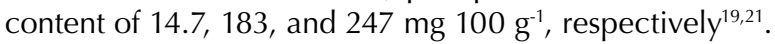
Maca consumption dates from $4000 \mathrm{BC}$ and is used in its dehydrated form, cooked, raw or as flour ${ }^{18}$. Maca flour has

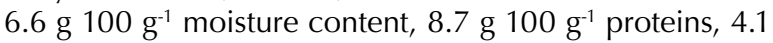

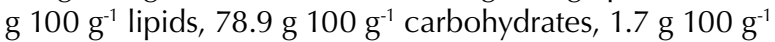

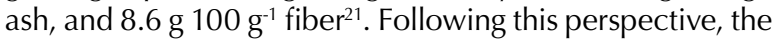
aim of this study was to obtain a GFB using maca flour and evaluate the physio-chemical and sensory characteristics. A Simplex Centroid Design was employed in order to choose the ideal proportions of pseudo-components of maca, potato starch, sweet and sour manioc flour.

\section{MATERIALS AND METHODS}

All ingredients -maca flour (Nutrigold, Jacarei, Brazil), rice flour (Vitão, Curitiba, Brazil), sweet manioc flour (Amafil, Cianorte, Brazil), sour manioc flour (Amafil), potato starch (Yoki, São Bernando do Campo, Brazil), sugar, salt, eggs, sunflower oil, Saccharomyces cerevisiae biological yeast, xanthan gum, and hydroxypropylmethylcellulose (HPMC) - were acquired in the local market of Foz do Iguaçu, Paraná, Brazil.

\section{Experimental mixture design}

A Simplex Centroid Design was used to develop a mixed flour employed in GFB samples elaboration. The influence of the percentage of maca flour, potato starch, sweet manioc flour and sour manioc flour were evaluated in the pseudo-components and a centroid point $\left(x^{11^{*}}, \mathrm{x}^{12^{*}}\right.$, $\mathrm{x}^{\prime 3^{*}}$ and $\mathrm{x}^{\prime 4^{*}}$, respectively). The responses were the specific volume and texture profile analysis (TPA) parameters (hardness, cohesiveness, springiness, and chewiness). The percentage of each variable was calculated relative to the proportion of mixed flour, composed of rice flour ( $52 \%$ fixed $=75.4 \mathrm{~g})$, maca flour (12 to $36 \%=17.4$ to $52.2 \mathrm{~g}$ ), potato starch $(12$ to $36 \%=17.4$ to $52.2 \mathrm{~g}$ ), sweet manioc flour ( 0 to $12 \%=$ 0 to $17.4 \mathrm{~g}$ ), and sour manioc flour ( 0 to $12 \%=0$ to $17.4 \mathrm{~g}$ ) according to the statistical modelling of the mixtures (Table 1). The mixed flour and GFB formulations were elaborated randomly, in duplicate, following the matrix described in table 1 . The other GFB ingredients were calculated and fixed based on total mixed flour (145 $\mathrm{g}=100 \%$ mixed flour), as following: sugar (15 g), sodium chloride (1.50 g), HPMC $(0.88 \mathrm{~g})$, xanthan gum $(2.50 \mathrm{~g})$, water $(50 \mathrm{~g})$, sunflower oil (18.8 g), egg (50 g), and dry yeast (2.50 g).

All ingredients were weighed in a semi-analytical balance (BL 3200H, Shimadzu, Kyoto, Japan) and dry ones were manually mixed for $30 \mathrm{~s}$. The mixture was added to the liquid ingredients (water was pre-heated to $38^{\circ} \mathrm{C}$ ) and blending in a planetary mixer (400W, Arno, São Paulo, Brazil) at speed 5 for $1 \mathrm{~min}$. The yeast (dissolved in $10 \mathrm{~mL}$ of water at $38^{\circ} \mathrm{C}$ ) was added to the dough and mixed at speed 1 for 2 mins. The dough was moulded into square aluminium 
Table 1. Matrix of mixture design with real and codified variables and responses analyzed for the gluten-free breads.

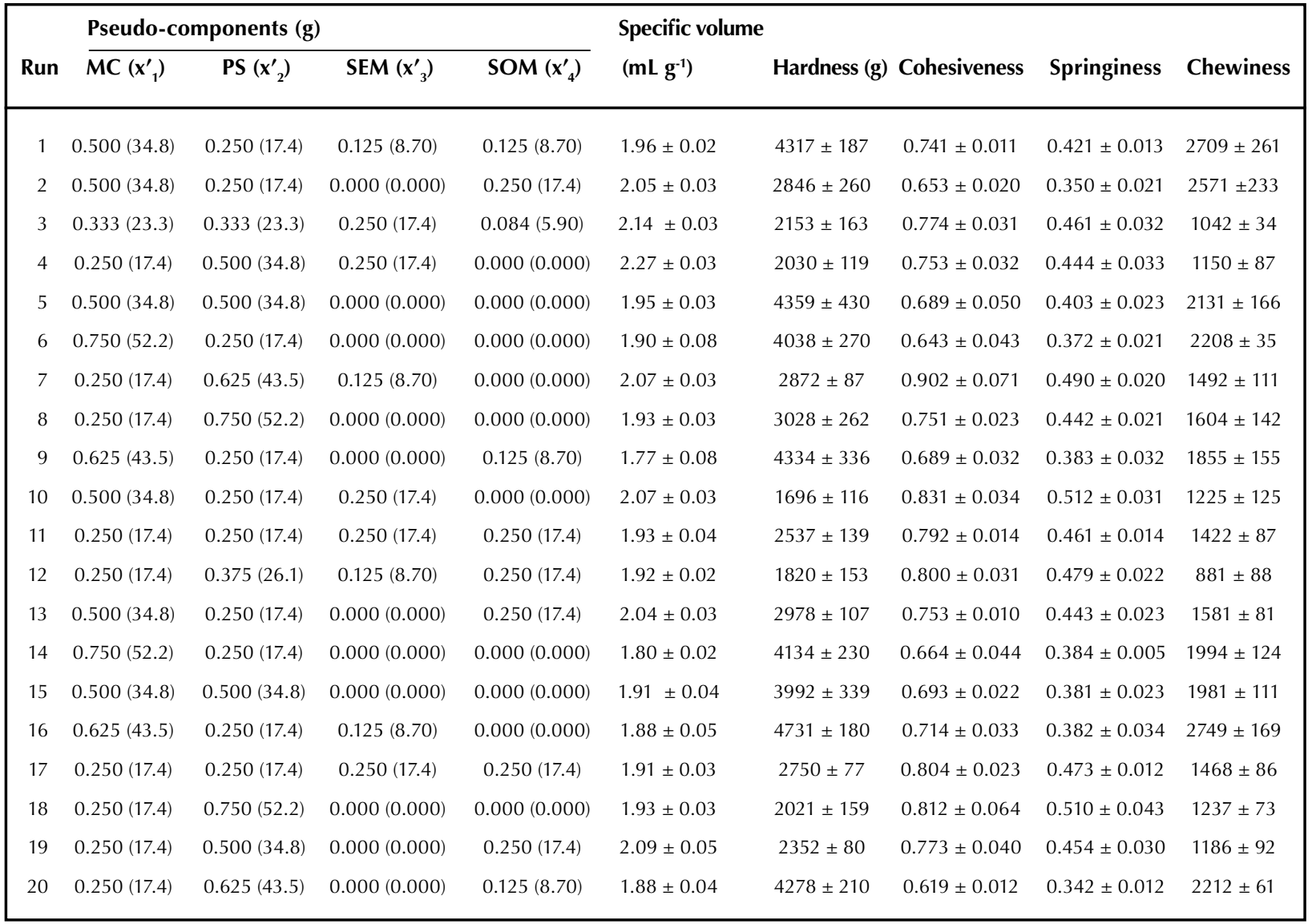

Pseudo-components: MC: maca; PS: potato starch; SEM: sweet manioc flour; SOM: sour manioc flour; $\mathrm{x}_{1}^{\prime}+\mathrm{x}_{2}{ }_{2}+\mathrm{x}^{\prime}{ }_{3}+\mathrm{x}_{4}^{\prime}=100 \%$ of mixed flour.

baking pans ( $11 \mathrm{~cm}$ wide $\times 9.50 \mathrm{~cm}$ high), greased with pork lard, kept in a fermentation chamber (Vipão 1.9, Perfecta, Curitiba, Brazil) with controlled humidity ( $80-85 \%$ relative humidity) at $40^{\circ} \mathrm{C}$ (mass fermentation process) for $50 \mathrm{~min}$. The baking was performed in a pre-heated industrial electric oven (Vipão 1.9, Perfecta) at $180{ }^{\circ} \mathrm{C}$ for 25 min. GFB was removed from the pans after cool and stored in polythene packages inside polypropylene boxes until analysis.

\section{Specific volume and texture profile analysis determination}

Specific volume $\left(\mathrm{mL} \mathrm{g}^{-1}\right)$ of GFB was determined by the ratio between the volume $(\mathrm{mL})$ and the mass of the bread (g) $1 \mathrm{~h}$ after cooking. The millet-seed displacement method was employed ${ }^{22}$.

Texture profile analysis (TPA) tests were performed in a texturometer (TAXT2i Texture Analyzer, Stable Micro System, Godalming, UK) in order to obtain the parameters of hardness, cohesiveness, springiness, and chewiness of GFB crumb ${ }^{23}$. The American Association of Cereal Chemists
(AACC) method 74-09 was employed ${ }^{24}$. GFB slices $(25 \mathrm{~mm}$ thickness) were used and the outer slices of both ends were discarded. The sliced were placed on the center platform of the texturometer to perform a compression test with a cylindrical probe (36 $\mathrm{mm}$ in diameter) under the following conditions: pre-test speed $1.00 \mathrm{~mm} \mathrm{~s}^{-1}$, test speed $1.7 \mathrm{~mm}$ $\mathrm{s}^{-1}$ and post-test speed $10 \mathrm{~mm} \mathrm{~s}^{-1}$. The compression was $40 \%$ of the height and trigger force was $5 \mathrm{~g}$. The tests were carried out $1 \mathrm{~h}$ after baking.

\section{Mixture design statistical analyses}

The statistical modelling of mixtures was composed of 20 experimental points. As outlined in table 1, the following experiments are equivalent: experiment $2=13$; $6=14 ; 8=18$; and $11=17$. The responses evaluated were expressed by mean \pm standard deviation $(n=4 ; 2$ GFB elaborated and analyzed in duplicate).

The present study applied the pseudo-components technique, due to the need to restrict the proportions of the four components that comprised the mixture in the production 
of GFB with maca. These intervals were justified by technical reasons, inside a closed interval between 0 and 1 . In this way, an experimental space was obtained, through a sub-region of that initially investigated. In the experimental data of each response were fitted a mathematical representation of the special cubic model for four pseudo-components (Equation 1). The upper and lower limits of pseudo-components were estimated according to Equation 2.

$$
\begin{aligned}
& y=b_{1}^{*} x_{1}^{\prime}+b_{2}^{*} x_{2+}^{\prime} b_{3}^{*} x_{3}^{\prime}+b_{4}^{*} x_{4}^{\prime} \\
& +b_{12}^{*} x_{1}^{\prime} x_{2}^{\prime}+b_{13}^{*} x_{1}^{\prime} x_{3}^{\prime}+b_{14}^{*} x_{1}^{\prime} x_{4}^{\prime}+b_{23}^{*} x_{2}^{\prime} x_{3}^{\prime}+b_{24}^{*} x_{2}^{\prime} x_{4}^{\prime}+b_{34}^{*} x_{3}^{\prime} x_{4}^{\prime} \text { Eq. (1) } \\
& +b_{123}^{*} x_{1}^{\prime} x_{3}^{\prime}+b^{*}{ }_{124} x_{1}^{\prime} x_{2}^{\prime} x_{4}^{\prime}+b_{134}^{*} x_{1}^{\prime} x_{3}^{\prime} x_{4}^{\prime}+b_{234}^{*} x_{2}^{\prime} x_{3}^{\prime} x_{4}^{\prime}
\end{aligned}
$$

Where: $y$ is the expected response, and $b_{1}^{*} \ldots b_{234}^{*}$ are the regression terms.

$0 \leq L_{i} \leq x_{i} \leq 1 ; i=1, \ldots, q$ Eq. (2)

Where: $L_{i}$ is the lower limit, and $U_{i}$ is the upper limit of the ratio of component $i$.

The coefficients and special cubic model adjustment were obtained by analysis of variance (ANOVA) for all investigated responses $(p<0.05)$ using the software Statistica 8.0. In order to define the best GFB formulation, the responses were optimized using the Response Desirability Profiling procedure. The goal was to maximize the specific volume and minimize hardness. The procedure computed a desirability value $(d i)$ of each response with significant special cubic model with di value ranges from 0 to $1 ; d i=1$ is the ideal case and $d i=0$ means that at least one response falls outside the desirable limits.

\section{Acceptance test and ethical aspects}

For acceptance tests, four GFB samples were selected and prepared $24 \mathrm{~h}$ before analysis. Based on the desirability results, run 4 (0.25 MC, 0.5 SP, 0.25 SEM, and 0 SOM) was chosen as the best option. Additionally, run 1 (centroid point), run 7 (lower level of maca), and run 14 (greater level of maca) were also sensory evaluated in order to compare. Tests were conducted in individual booths, under white light. GFB slices were cut in 4 similar portions ( $\cong 30 \mathrm{~g}$ ) and served in a white plastic plate codified with three randomized digits in a monadic way. Consumers were instructed to clean the palate with water before and between samples. The participants were university students, teachers and employees, of both genders, all above 18 years of age and regular bread consumers. The panel of 112 consumers evaluated the GFB samples using a 9-point hedonic scale anchored with verbal terms $(1=$ extreme dislike, $5=$ neither liked, nor disliked, $9=$ extremely liked), regarding the attributes of color, aroma, texture, flavor, and overall acceptance. The acceptability index was calculated according to Teixeira et al. ${ }^{25}$. The present study was authorized by the Ethics Committee of UTFPR (Certificate of Ethical Evaluation Presentation $013192 / 2016)$. The acceptance data were expressed as mean \pm standard deviation and evaluated by a main effects
ANOVA and Tukey test procedure using the Statistica 8.0 software $(p<0.05)$.

\section{Proximate composition, caloric value and microbiological analysis}

Four GFB formulations (1, 4, 7 and 14) selected for sensory tests were analyzed regarding proximate composition and microbiological analysis. The moisture and volatile matter content (method no. 925.10), crude protein (method no. 920.87; nitrogen-converting factor of 5.7) and ash (method no. 923.3) were determined in GFB according the Association of Official Analytical Chemists ${ }^{26}$. Total lipids were extracted and determined according to Bligh \& Dyer ${ }^{27}$ and total carbohydrate was calculated by difference. The caloric value of GFB was determined using a calorimeter with isoperibolic measurement (C-200, Ika Works, Staufen, Germany).

The count of coliforms at $45{ }^{\circ} \mathrm{C}$ (method 08101) and coagulase-positive staphylococci (method 997.02) in GFB were determined according $\mathrm{AOAC}^{26}$. The absence or presence of Salmonella sp. was determined according International Organization for Standardization (ISO 6579) ${ }^{28}$. The cited analyses were performed in order to attend the parameter stipulated by Resolution RDC n. $12^{29}$. The data were expressed by mean \pm standard deviation $(n=4)$ and evaluated by a one-way ANOVA and Tukey test $(\mathrm{p}<0.05)$ using Statistica 8.0.

\section{RESULTS}

All formulations resulted in GFB with golden, bright, homogeneous, thin, consistent and well-defined crusts as described in figure 1. All the formulations presented a consistent and homogeneous crumb without holes that compromised bread structure. Formulations 6, 14, 9 and 16 (with 0.75 and 0.625 maca proportions) presented crumbs with fewer alveoli compared to other GFB formulations. Among these formulations, run 9 had a more homogeneous core, which can be correlated to dough fermentation.

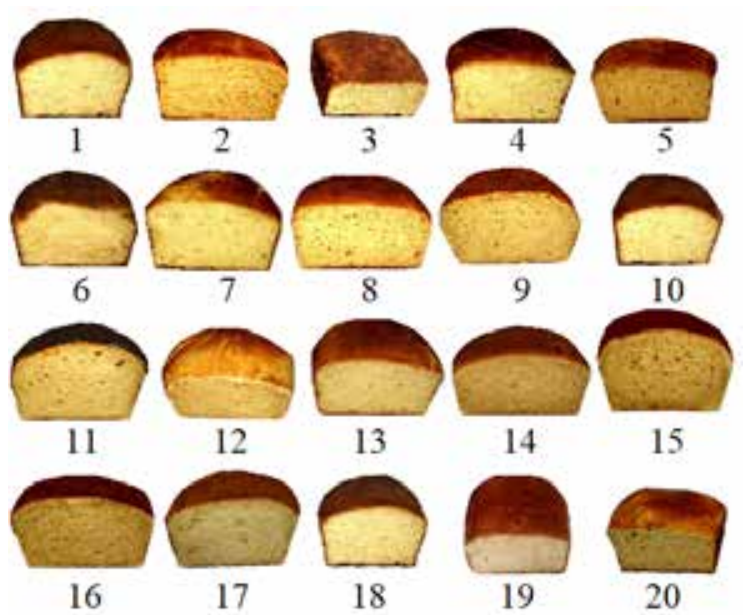

Figure 1: Appearance of the internal and external structure of the gluten-free bread. 


\section{Simplex Centroid Design and desirability response}

The matrix of GFB elaborated and the responses of specific volume, hardness, cohesiveness, springiness, and chewiness are presented in table 1 . The specific volume varied between 1.77 and $2.27 \mathrm{~mL} \mathrm{~g}^{-1}$. The hardness ranged from 1696 and 4731 $\mathrm{g}$, cohesiveness from 0.619 and 0.902 , springiness between 0.342 and 0.512 and chewiness from 881 to 2709 (Table 1). The experimental results obtained by the special cubic model for all responses were statistically evaluated, and the calculated regression coefficients are shown in table 2 .

The special cubic model provided the best adjustment for the specific volume data with a $R^{2}=0.975$ and adjusted $R^{2}=$ 0.932. All pseudo-component studied generated a significant increase in the specific volume $(p<0.05)$. The interaction MC/SEM, MC/SOM, PS/SOM, SEM/SOM and PS/SEM/SOM had negative influence in specific volume, while the ternary interaction MC/SEM/SOM was the only one with a positive effect in the variable studied $(\mathrm{p}<0.05)$.

The special cubic model provided the best adjustment for the hardness data with a $R^{2}=0.913$ and adjusted $R^{2}=0.765$. For hardness, the pseudo-components MC and PS had positive coefficients, while the SEM and SOM had negative coefficients $(p<0.05)$. All binary interactions of pseudo-components were positive and only the MC/PS was not significant. The ternary interaction PS/SEM/SOM was also significant, with a negative coefficient $(p<0.05)$.

However, in the range studied for pseudo-components the responses of cohesiveness, springiness and chewiness were influenced by all other GFB ingredients. This was evidenced by the significant lack of fit of the special cubic model. All three responses were adjusted with a linear model; however, the $\mathrm{R}^{2}$ and adjusted $R^{2}$ were lower, $<0.5$ and $<0.4$ respectively, for all responses (Table 2). Thus, the cohesiveness, springiness and chewiness were not considered in the desirability function.

Run 4 was considered, by desirability response, the best mixed flour added to GFB formulation regarding the higher specific volume and lower hardness values predicted by models (Figure 2). To the GFB was added 0.25 of MC, 0.5 of PS, 0.25 of SEM and 0 of SOM. This mixed flour composition (run 4) presented the most expected interactions between pseudo-components in the elaboration of the GFB, according to the convenience of the factors investigated in the statistical modelling of the mixtures.

Table 2. Regression models for specific volume and TPA parameters of gluten-free breads.

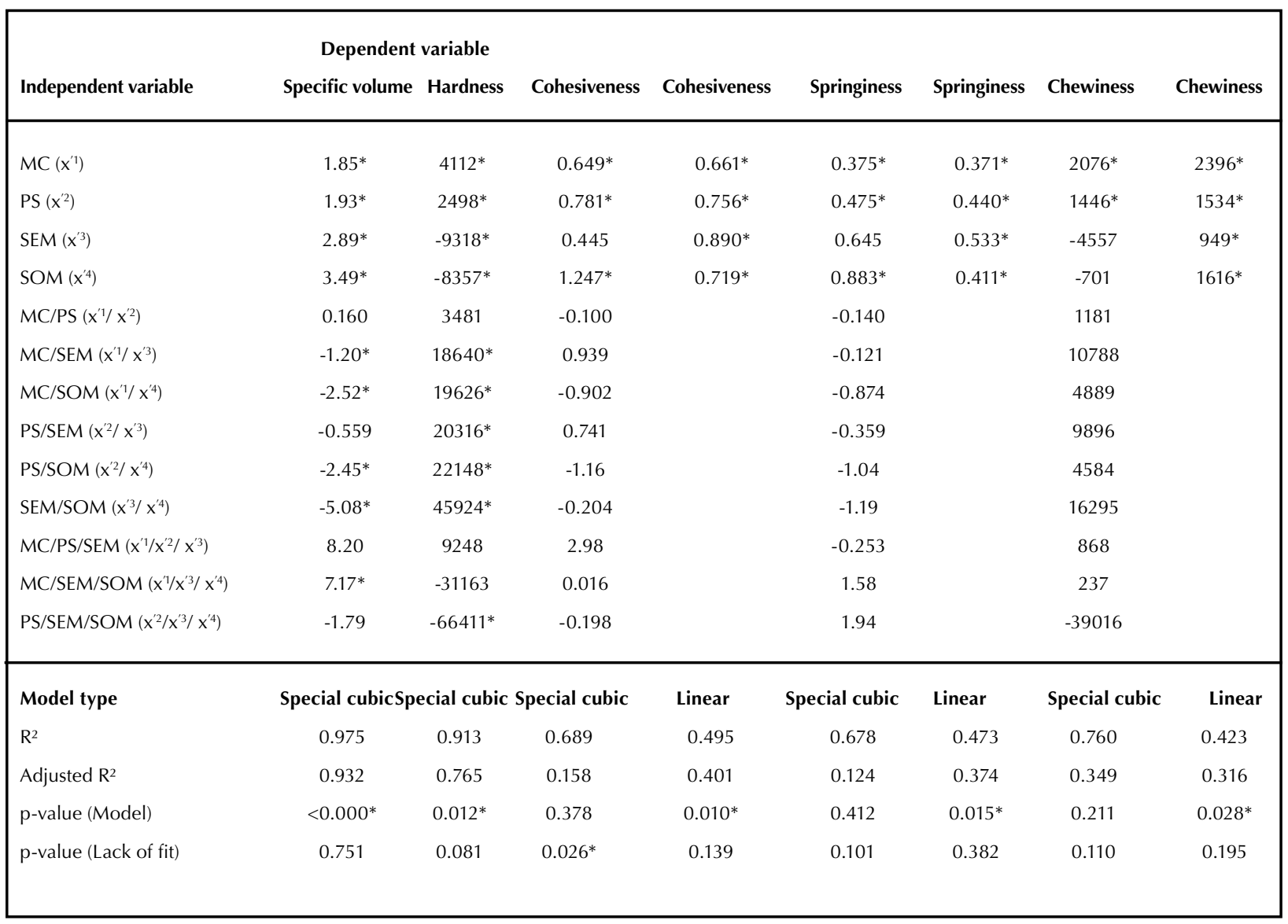

Pseudo-components: MC: maca; PS: potato starch; SEM: sweet manioc flour; SOM: sour manioc flour; ${ }^{*} \mathrm{p}<0.05$. 


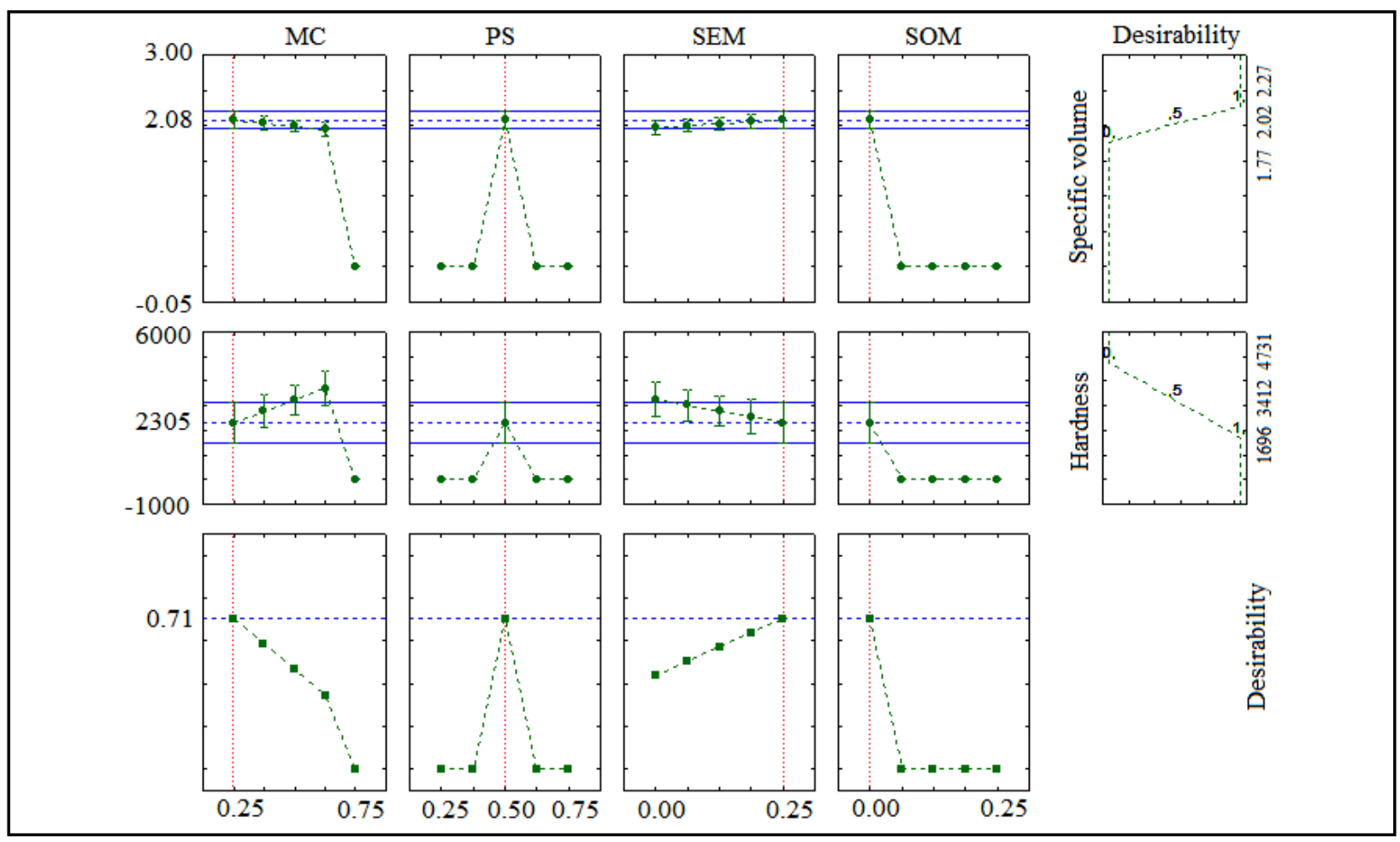

Figure 2: Desirability graph of the statistical modelling of mixtures for gluten-free bread elaboration.

Pseudo-components: MC: maca; PS: potato starch; SEM: sweet manioc flour; SOM: sour manioc flour; the dotted vertical line represents global convenience.

\section{Sensory analysis}

All GFB formulation were sensorially accepted, with an acceptability index greater than $72.4 \%$, with sensory scores varying between 6.52 and 7.42 (Table 3). The aroma, color, flavour and overall acceptance had similar grades for all GFB evaluated $(p<0.05)$. However, for texture, run 14 was more accepted than run 4 and $7(p<0.05)$ and had similar a grade to run 1 .

Table 3. Sensory acceptance of gluten-free breads.

\begin{tabular}{|llcccc|}
\hline & Attributes & Run 1 & Run 4 & Run 7 & Run 14 \\
\hline Sensory & Aroma & $6.66 \pm 1.83^{\mathrm{a}}$ & $6.71 \pm 1.78^{\mathrm{a}}$ & $6.60 \pm 1.82^{\mathrm{a}}$ & $6.70 \pm 1.76^{\mathrm{a}}$ \\
mean & Color & $7.37 \pm 1.41^{\mathrm{a}}$ & $7.22 \pm 1.43^{\mathrm{a}}$ & $7.26 \pm 1.43^{\mathrm{a}}$ & $7.27 \pm 1.41^{\mathrm{a}}$ \\
& Texture & $7.08 \pm 1.64^{\mathrm{ab}}$ & $6.65 \pm 1.80^{\mathrm{b}}$ & $6.52 \pm 1.89^{\mathrm{b}}$ & $7.42 \pm 1.67^{\mathrm{a}}$ \\
& Flavor & $7.02 \pm 1.80^{\mathrm{a}}$ & $6.75 \pm 1.77^{\mathrm{a}}$ & $6.92 \pm 1.62^{\mathrm{a}}$ & $7.09 \pm 1.80^{\mathrm{a}}$ \\
& Overall acceptance & $7.17 \pm 1.59^{\mathrm{a}}$ & $6.83 \pm 1.59^{\mathrm{a}}$ & $6.87 \pm 1.43^{\mathrm{a}}$ & $7.32 \pm 1.51^{\mathrm{a}}$ \\
Acceptability & & & & $74.4 \%$ \\
& Aroma & $74.0 \%$ & $74.6 \%$ & $73.3 \%$ & $80.8 \%$ \\
& Color & $81.9 \%$ & $80.2 \%$ & $80.7 \%$ & $82.4 \%$ \\
& Texture & $78.7 \%$ & $73.9 \%$ & $72.4 \%$ & $78.8 \%$ \\
& Flavor & $78.0 \%$ & $75.0 \%$ & $76.9 \%$ & $76.3 \%$ \\
\hline
\end{tabular}

Mean \pm standard deviation $(n=112)$; different letters in the same line indicate significant differences by Tukey test $(p<0.05)$. 


\section{Physio-chemical and microbiological parameters}

All GFB elaborated had similar values of moisture, ash, protein, lipid and caloric value $(p>0.05)$ and only the carbohydrate value was lower in run 4 compared to run 14 (with 0.75 of maca) ( $p>0.05)$ (Table 4). Thus, an increase in the maca content (from 0.25 to 0.75 ) improved carbohydrate content.

GFB elaborated samples (run 1, 4, 7 and 14) had 3 MPN g-1 for coliforms at $45^{\circ} \mathrm{C}$ and absence of Salmonella sp. as described in table 4 . The microbiological parameter evaluated attested to the satisfactory hygienic and sanitary conditions of GFB elaboration.

\section{DISCUSSION}

The appearance of GFB (Figure 1) demonstrated that the interaction between the ingredients was positive for the formation of this type of crust. Maca has between 54.6 and $60 \%$ of total carbohydrates, among them, $23.4 \%$ is sucrose $^{19}$. This information may suggest that the maca and sugar present in the dough contributed to the caramelization that defined the expected crust characteristics of the bread by consumers. Additionally, the homogeneous core of run 9 should be correlated to the fermentation of the dough. The bread fermentation step represents a decisive factor in the constitution of the alveoli, with carbon dioxide $\left(\mathrm{CO}^{2}\right)$ bubble retention in the dough ${ }^{22}$. The presence of SOM in the GFB may also contribute to the formation of a quality crumb in the absence of a leavening agent, since it is a modified starch with expansion property ${ }^{30}$. As it is a fermented starch, the SOM is more water-soluble, with a greater property of water adsorption and less viscosity relative to SEM. Bakery products expansion is compromised by the addition of starch in its natural state ${ }^{31}$.

\section{Simplex Centroid Design and desirability response}

Regarding the specific volume, hardness, cohesiveness, springiness and chewiness, no data have been reported in the literature regarding the adding of maca flour to GFB. However, GFB described in the current article had values of specific volume, hardness, cohesiveness, and chewiness (Table 1) in the range observed for GFB produced by adding different vegetal products. Data available in the literature for the specific volume ranged from 1.28 and $2.87 \mathrm{~mL} \mathrm{~g}^{-1}$ for GFB elaborated by a combination of two or more base ingredients, including rice flour, corn starch, potato starch, buckwheat, sorghum, and quinoa $3,13,15,32,33$. Hardness ranges between 810 and $6000 \mathrm{~g}$ for GFB elaborated with corn starch or rice flour as the main ingredient, while chewiness varies from 700 and 2600 in rice flour based $\mathrm{GFB}^{13,34}$. The cohesiveness values of GFB are in the range described for GFB (0.24 to 0.82$)$ based on corn starch, rice flour, potato starch and/or sorghum flour ${ }^{13,32,33,34,35}$. The GFB elaborated samples that had lower springiness values compared to data reported for GFB with rice flour, corn starch, and/or potato starch, described in the range from 0.72 to $13,32,34,35$. The lower springiness of GFB elaborated indicates that, although the texture is initially firmer, a single compression significantly destroys its structure preventing any springback. In practice, the GFB does not recover its structure well after it is compressed ${ }^{36}$.

Table 4. Proximal composition (dry basis), caloric value, and microbiological parameters for gluten-free breads.

\begin{tabular}{|c|c|c|c|c|}
\hline Parameter & Run 1 & Run 4 & Run 7 & Run 14 \\
\hline Moisture (g $\left.100 \mathrm{~g}^{-1}\right)$ & $27.4 \pm 1.30^{a}$ & $30.92 \pm 2.16^{\mathrm{a}}$ & $30.79 \pm 1.06^{a}$ & $27.13 \pm 1.09^{a}$ \\
\hline Ash $\left(g 100 \mathrm{~g}^{-1}\right)$ & $1.69 \pm 0.141^{\mathrm{a}}$ & $1.50 \pm 0.052^{\mathrm{a}}$ & $1.50 \pm 0.103^{a}$ & $1.77 \pm 0.613^{a}$ \\
\hline Protein $\left(\mathrm{g} 100 \mathrm{~g}^{-1}\right)$ & $14.2 \pm 0.482^{\mathrm{a}}$ & $15.3 \pm 0.734^{\mathrm{a}}$ & $13.9 \pm 1.063^{\mathrm{a}}$ & $14.3 \pm 0.522^{\mathrm{a}}$ \\
\hline Lipids (g $100 \mathrm{~g}^{-1}$ ) & $12.2 \pm 0.695^{\mathrm{a}}$ & $12.8 \pm 0.632^{\mathrm{a}}$ & $12.3 \pm 0.931^{\mathrm{a}}$ & $11.1 \pm 0.381^{\mathrm{a}}$ \\
\hline Carbohydrates $\left(\mathrm{g} 100 \mathrm{~g}^{-1}\right)$ & $72.0 \pm 0.652^{\mathrm{ab}}$ & $70.4 \pm 0.863^{b}$ & $72.3 \pm 1.11^{\mathrm{ab}}$ & $72.8 \pm 0.284^{\mathrm{a}}$ \\
\hline Caloric value $\left(\mathrm{kcal} 100 \mathrm{~g}^{-1}\right)$ & $329 \pm 8.55^{a}$ & $316 \pm 8.10^{\mathrm{a}}$ & $315 \pm 11.75^{\mathrm{a}}$ & $326 \pm 7.22^{a}$ \\
\hline Salmonella sp. (in $25 \mathrm{~g}$ ) & Absence & Absence & Absence & Absence \\
\hline Coliforms at $45^{\circ} \mathrm{C}\left(\mathrm{MPN} \mathrm{g}^{-1}\right)$ & 3.0 & 3.0 & 3.0 & 3.0 \\
\hline \multicolumn{5}{|l|}{ Staphylococcus positive } \\
\hline coagulase $\left(\mathrm{CFU} \mathrm{g}^{-1}\right)$ & $<10^{1}$ & $<10^{1}$ & $<10^{1}$ & $<10^{1}$ \\
\hline
\end{tabular}

Mean \pm standard deviation $(n=4)$; MPN: most probable number; CFU: colony forming unit; different letters in the same line indicate significant differences by Tukey test $(p<0.05)$. 
Higher specific volume predicted by a special cubic model (Table 2) is appropriate for sensory acceptance of breads. However, GFB presents difficulties in the expansion of the dough, as GFB does not retain the gas formed during the fermentation period, which compromises the specific volume of the product ${ }^{6}$. However, the addition of starches, such as maca, which, due to the high amount of sucrose, contributes to the increase in the fermentation. The SEM fulfils the role of gum in the interaction between the components of the bread, and the expansion contributed by the SOM, helps in the retention of $\mathrm{CO}^{2}$ gas in the amplification of the specific volume ${ }^{37}$.

Hardness represents the force necessary to attain a given deformation ${ }^{23}$. Breads with lower hardness were considered more accepted by consumers; GFB had up to 10 times the hardness than that obtained by wheat flour, which relates to high density and reduced compressibility ${ }^{36}$. According to the special cubic model obtained for hardness (Table 2), the high content of fiber of MC and PS can explain the hardness increase ${ }^{6}$, while the SEM and SOM, with lower fiber content and different effects in the dough -gelatinization at lower temperatures in GFB related other starch sources ${ }^{38}-$ had a negative impact for hardness.

Cohesiveness, springiness and chewiness are important parameters for GFB, but isolated, were not considered criteria for an increase or decrease in quality. Cohesiveness was an indicator of internal cohesion of the material. Generally, breads with low cohesiveness are susceptible to fracture and crumble ${ }^{6}$. Springiness represents the rate at which a bread is deformed and the product goes back to its undeformed condition after the deforming force is removed $^{23}$. Chewiness gives an indication of the energy required to masticate a solid food and therefore the time required masticating a bread piece prior to swallow 6 . In the present study, considering the range studied for pseudocomponents, the cohesiveness, springiness and chewiness suffer influence from other GFB ingredients and had only a linear significant model $(p<0.05)$ (Table 2$)$.

\section{Sensory analysis}

The result of the sensory test (Table 3 ) demonstrated that the higher amount of maca $(0.75$ and 0.5 for run 14 and 1$)$ in the GFB positively influenced texture acceptance. Lower hardness is associated with higher sensory acceptance, as lower hardness correlates with bread freshness ${ }^{15}$. The high sucrose content of maca can contribute to the improvement of texture acceptance ${ }^{19}$, because, according to Morais et al. ${ }^{39}$, sweetener can influence the softness acceptance of GFB. However, it important to emphasize that the panel was composed of all consumers (not only those who ate glutenfree), thus consumers were not necessarily accustomed to the texture of gluten-free products.

\section{Physio-chemical and microbiological parameters}

The values of the physio-chemical parameters obtained in the present article (Table 4) was in the range described for GFB in the literature. The data reported by other authors range from 1.36 and $2.86{\mathrm{~g} 100 \mathrm{~g}^{-1} \text { for ash }}^{10,11,14,15}$, between 6.5 and $13.6{\mathrm{~g} 100 \mathrm{~g}^{-1} \text { for lipids }}^{10,11,14}$, from 3.3 to 14 for protein ${ }^{11,12,15}$, and between 62.9 and $83.9 \mathrm{~g} 100$ $\mathrm{g}^{-1}$ for carbohydrates $10,11,12,14$. The exception was moisture that was lower than the range described by literature data

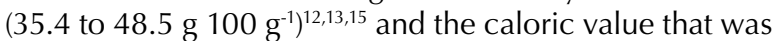

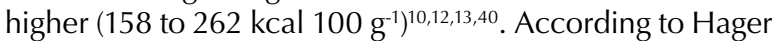
et al. ${ }^{40}$, a lower moisture content implies a higher caloric value in breads.

Table 4 shows the microbiological parameter results attesting the satisfactory hygienic and sanitary conditions of GFB elaboration, according to the limit tolerated of 100 NMP g-1 for coliforms at $45{ }^{\circ} \mathrm{C}$ and absence of Salmonella $\mathrm{sp.}^{29}$. The Staphylococcus coagulase positive counts were < $10^{1} \mathrm{CFU} \mathrm{g}^{-1}$, indicating that the processing method applied in the present study allowed the formulation of a GFB suitable for human consumption.

\section{CONCLUSION}

The responses specific volume and hardness were well adjusted using a special cubic model considering the Simplex Centroid Design with the pseudo-components MC, PS, SEM and SOM in GFB elaboration. The significant contribution of maca to the GFB dough was evident in the models and the desirability results indicated an appropriate mixed flour composed by 0.250 of MC, 0.500 of PS, 0.250 of SEM and 0.00 of SOM. The GFB elaborated with this mixed flour generated a product well accepted (acceptability index higher than $73.9 \%$ ) for all attributes evaluated. The values of physio-chemical parameters obtained in the present article was in the range described for GFB in the literature and the processing method applied in the present study allowed for microbiological stability.

Conflict of Interest. The authors declare that they have no interest or benefit arising from the direct applications of this manuscript.

Acknowledgements. The authors would like to thank to Capes, CNPq, Fundação Araucária and Universidade Tecnológica Federal do Paraná.

\section{REFERENCES}

1. Liu SM, Resende PVG, Bahia M, Penna FJF, Ferreira AR, Liu PMF, Antunes Neto AS, Santos LRA, Eliazar GC, Arantes Júnior MAF. Celiac Disease. Rev Med Minas Gerais. 2014; 24: S38-S45.

2. Resende PVG, Silva NLM, Schettino GCM, Liu PMF. Gluten related disorders. Rev Med Minas Gerais. 2017; 27: S51-S58

3. Bourekoua H, Różyło R, Benatallah L, Wójtowicz A, tysiak G, Zidoune MN, Sujak A. Characteristics of gluten - free bread: quality improvement by the addition of starches/hydrocolloids and their combinations using a definitive screening design. Eur Food Res Technol. 2017; 244: 345-354.

4. Época. Brasileiro aumenta consumo de alimentos sem glúten e lactose. 2018. Available at: https://epocanegocios.globo.com/ 
Economia/noticia/2018/06/brasileiro-aumenta-consumo-dealimentos-sem-gluten-e-lactose.html. Accessed 14 Feb 2019.

5. Sciarini LS, Ribotta PD, León AE, Pérez GT. Effect of hydrocolloids on gluten-free batter properties and bread quality. Int J Food Sci Technol. 2010; 45: 2306-2312.

6. Paciulli $M$, Rinaldi $M$, Cirlini $M$, Scazzina F, Chiavaro $E$. Chestnut flour addition in commercial gluten-free bread: $A$ shelf-life study. LWT - Food Sci Technol. 2016; 70: 88-95.

7. Pellegrini N, Agostoni C. Nutritional aspects of gluten-free products. I Sci Food Agric. 2015; 95: 2380-2385.

8. Thompson T, Dennis M, Higgins LA, Lee AR, Sharrett MK. Gluten-free diet survey: Are Americans with coeliac disease consuming recommended amounts of fibre, iron, calcium and grain foods? J Hum Nutr Diet. 2005; 18: 163-169.

9. Saturni L, Ferretti G, Bacchetti T. The gluten-free diet: Safety and nutritional quality. Nutrients. 2010; 2: 16-34.

10. Alencar, NMM, Steel CI, Alvim ID, Morais EC, Bolini HMA. Addition of quinoa and amaranth flour in gluten-free breads: temporal profile and instrumental analysis. LWT - Food Sci. Technol. 2015; 62: 1011-1018.

11. Capriles VD, Arêas JAG. Effects of prebiotic inulin-type fructans on structure, quality, sensory acceptance and glycemic response of gluten-free breads. Food Funct. 2013; 4: $104-110$

12. Costantini L, Lukšič L, Molinari R, Kreft I, Bonafaccia G, Manzi L, Merendino N. Development of gluten-free bread using tartary buckwheat and chia flour rich in flavonoids and omega-3 fatty acids as ingredients. Food Chem. 2014; 165: 232-240.

13. Huerta KM, Boeira CP, Soquetta MB, Alves JS, Kubota EH, Rosa CS. The effect of chia (Salvia hispanic L.) flour as a substitute for fat in gluten-free bread. Nutr Food Sci. 2018; 49: 517-527.

14. Pereira BS, Cardoso ES, Mendonça JOB, Souza LB, Santos MP, Zago L. Physical, chemical and sensory analysis of gluten-free potato bread enriched with chia flour. Demetra Aliment Nutr Saúde. 2013; 8: 125-136.

15. Turkut GM, Cakmak H, Kumcuoglu S, Tavman S. Effect of quinoa flour on gluten-free bread batter rheology and bread quality. J Cereal Sci. 2016; 69: 174-181.

16. Gonzales C, Rubio I, Gasco M, Nieto J, Yucra S, Gonzales GF. Effect of short-term and long-term treatments with three ecotypes of Lepidium meyenii (maca) on spermatogenesis in rats. J Ethnopharmacol. 2006; 103: 448-454.

17. Gonzales GF, Villaorduña L, Gasco M, Rubio I, Gonzales C. Maca (Lepidium meyenii Walp), a review ot its biological properties. Rev Peru Med Exp Salud. 2014; 31: 100-110.

18. Pino-Figueroa A, Nguyen D, Maher TJ. Neuroprotective effects of Lepidium meyenii (Maca). Ann N Y Acad Sci. 2010; 1199: 77-85.

19. Sifuentes-Penagos G, León-Vásquez S, Paucar-Menacho LM. Study of Maca (Lepidium meyenii Walp.), Andean crop with therapeutic properties. Sci Agropecu. 2015; 6: 131140.

20. Zha S, Zhao Q, Chen J, Wang L, Zhang G, Zhang H, Zhao B. Extraction, purification and antioxidant activities of the polysaccharides from maca (Lepidium meyenii). Carbohydr Polym. 2014, 111: 584587.

21. García MR, Prieto IG-S, Barrientos CE. Tablas peruanas de composición de alimentos. Ministerio de Salud, Lima, 2017.

22. El-Dash AA, Camargo CRO, Diaz N. Fundamentos de Tecnologia de Panificação. Série Agro-Industrial 6, São Paulo, 1982
23. Szczesniak AS. Texture is a sensory property. Food Qual. Prefer. 2002; 13: 215225.

24. AACC. American Association for Clinical Chemistry. Approved Methods of the AACC. $9^{\text {th }}$ ed. Saint Paul, 1995.

25. Teixeira E, Meinert EM, Barbetta PA. Análise sensorial de alimentos. UFSC, Florianópolis, 1987.

26. AOAC. Association of Official Agricultural Chemists. Official methods of analysis of the AOAC. $16^{\text {th }}$ ed. Washington, 1995.

27. Bligh EG, Dyer WJ. A rapid method of total lipid extraction and purification. Can J Biochem Physiol. 1959; 37: 911-917.

28. ISO. International Organization for Standardization. ISO 6579: 2002. Microbiology of food and animal feeding stuffs - Horizontal method for the detection of Salmonella spp. Genève, 2002.

29. Brazil. (Health Ministry). Collegiate Board of Directors Resolution No. 12 from 02 Jan 2001. To approve the technical regulation on microbiological standards for foods. Available at: http://portal.anvisa.gov.br/documents/33880/2568070/ RDC_12_2001.pdf/15ffddf6-3767-4527-bfac-740a0400829b. Accessed 14 Feb 2019.

30. Cereda MP, Franco CML, Daiuto ER, Demiate IM, Carvalho $L J$, Leonel M, Vilpoux OF, Sarmento SBS. Propriedades gerais do amido. Fundação Cargill, Campinas, 2001.

31. Sanchez HD, Osella CA, Torre MA. Optimization of glutenfree bread prepared from cornstarch, rice flour, and cassava starch. / Food Sci. 2002; 67: 416-419.

32. Moore MM, Schober TJ, Dockery P, Arendt EK. textural comparisons of gluten-free and wheat-based doughs, batters, and breads. Cereal Chem. 2004; 81: 567-575.

33. Schober TI, Messerschmidt M, Bean SR, Park S, Arendt EK. Gluten-free bread from sorghum: quality differences among hybrids. Cereal Chem. 2005; 82: 394-404.

34. Encina-Zelada $C R$, Cadavez V, Monteiro F, Teixeira JA, Gonzales-Barron U. Combined effect of xanthan gum and water content on physicochemical and textural properties of gluten-free batter and bread. Food Res Int. 2018; 111: 544-555.

35. Matos ME, Rosell CM. Relationship between instrumental parameters and sensory characteristics in gluten-free breads. Eur. Food Res Technol. 2012; 235:107-117.

36. Brookfield. Update on Wheat vs. Gluten-Free Bread Properties. 2019. Available at: https://www.brookfieldengineering. com/-/media/ametekbrookfield/articles/texture/update on wheat vs gluten-free bread properties.pdf?la=en. Accessed 14 Feb 2019.

37. Onitilo MO, Sanni LO, Oyewole OB, Maziya-Dixon B. Physicochemical and functional properties of sour starches from different cassava varieties of sour starches from different cassava varieties. Int J Food Properties. 2007; 10: 607-620.

38. Duodu KG, Taylor JRN. The quality of breads made with non-wheat flours. Cauvain SP, ed., Breadmaking, 2nd. Elsevier, Amsterdam 2012, p. 754-782.

39. Morais EC, Cruz AG, Bolini MA. Gluten-free bread : multiple time - intensity analysis, physical characterisation and acceptance test. Int J Food Sci Technol. 2013; 48: 21762184.

40. Hager A-S, Wolter A, Czerny M, Bez J, Zannini E, Arendt EK, Czerny M. Investigation of product quality, sensory profile and ultrastructure of breads made from a range of commercial gluten-free flours compared to their wheat counterparts. Eur Food Res. Technol. 2012; 235: 333-344. 